\title{
Realizing the transformative potential of conservation through the social sciences, arts and humanities ${ }^{1}$
}

Authors: Nathan J. Bennett ${ }^{1,2,3}$ (nathan.bennett@ubc.ca) and Robin Roth ${ }^{4}$ (rroth01@uoguelph.ca)

\section{Affiliations:}

1) Institute for Resources, Environment and Sustainability, University of British Columbia, Vancouver, BC, Canada, V6T 1 Z4

2) University of Nice Sophia Antipolis, Nice, France, 06100

3) Center for Ocean Solutions, Stanford University, Pacific Grove, CA, USA, 93950

4) University of Guelph, Guelph, ON, Canada, N1G 2W1

Abstract: Conservation actions most often occur in peopled seascapes and landscapes. As a result, conservation decisions cannot rely solely on evidence from the natural sciences, but must also be guided by the social sciences, the arts and the humanities. However, we are concerned that too much of the current attention is on research that serves an instrumental purpose, by which we mean that the social sciences are used to justify and promote status quo conservation practices. The reasons for engaging the social sciences, as well as the arts and the humanities, go well beyond making conservation more effective. In this editorial, we briefly reflect on how expanding the types of social science research and the contributions of the arts and the humanities can help to achieve the transformative potential of conservation.

Keywords: conservation social science; environmental social science; conservation science; environmental humanities; environmental ethics; conservation policy

Conservation actions most often occur in peopled seascapes and landscapes. As a result, conservation decisions cannot rely solely on evidence from the natural sciences, but must also be guided by the social sciences, the arts and the humanities. The welldocumented risks and harms of ignoring the human dimensions of conservation are substantial, with past conservation initiatives engaging in exclusionary planning and implementation processes, producing significant negative social impacts and leading to

\footnotetext{
${ }^{1}$ This is a post-print version of the following article, please cite as follows: Bennett, N.J. \& Roth, R. (2018). Realizing the transformative potential of conservation through the social sciences, arts and humanities. Biological Conservation. Link to original article: https://doi.org/10.1016/j.biocon.2018.07.023
} 
conservation backlash (Holmes and Cavanagh, 2016; West et al., 2006; West and Brockington, 2006). Acknowledging these negative consequences has led to a greater recognition of the need to pay attention to the social aspects of planning and ongoing management of conservation initiatives. There has been subsequent calls for the 'mainstreaming of the social sciences in conservation' (Bennett et al., 2017b). The conservation social sciences are a rigorous set of disciplines, theories and methods for systematically understanding and characterizing the human dimensions to facilitate evidence-based conservation (see Bennett et al., 2017a; Charnley et al., 2017; Moon and Blackman, 2014). While the potential contributions of the conservation social sciences are vast, we are concerned that too much of the current attention is on research that serves an instrumental purpose, by which we mean that the social sciences are used to justify and promote status quo conservation practices. The reasons for engaging the social sciences, as well as the arts and the humanities, go well beyond making conservation more effective. In this editorial, we briefly reflect on how expanding the types of social science research and the contributions of the arts and the humanities can help to achieve the transformative potential of conservation.

First, the set of topics that are examined by conservation social scientists needs to be expanded exponentially. The "human dimensions" include an exceedingly broad set of social, economic, cultural, health, political and governance considerations. Yet, despite the wide array of potential sub-topics that might be included under each of these areas of consideration, some social science topics continue to receive substantially more attention than others. For example, topics such as economic and non-economic valuation of nature, behavior change, management effectiveness, enforcement, and human-wildlife interactions are highly represented in the conservation literature. We posit that these topics receive more attention because they are instrumental to conservation and management actions. They serve a clear purpose: to justify conservation and improve environmental outcomes. Topics such as governance, culture, social impacts, politics, power relations, ethics, narratives and knowledge receive significantly less attention. Many conservation scientists and practitioners may find these areas of research more demanding, as results and insights could challenge status quo conservation practice or lead to questions about the underlying philosophy of conservation. Social science might reveal hidden economic or political agendas (Gray et al., 2014; Harris, 2014) or problematic ideologies, visions or values that are producing conflict and undermining conservation (Chan et al., 2016; Doak et al., 2014). However, we believe that conservationists should not be afraid to engage with challenging or critical social science scholarship on conservation, as these ideas may produce more transformative insights into how to adaptively manage and improve conservation policy and practice. Critical appraisals may inspire novel insights while leading to more constructive solutions. This will require respectful dialogue between those examining 
and debating hot-button issues from different theoretical standpoints - for example, such a measured discussion would benefit the contentious "half-earth" proposal (Büscher et al., 2017; Wilson, 2016). Finally, all social science topics on conservation geographies, species, environments and initiatives that have been less popular to research deserve additional attention - for example, the human dimensions of invasive species (Head, 2017) or large-scale marine protected areas (Gruby et al., 2016).

Second, the arts and humanities have an exceedingly important role to play in conservation (Holm et al., 2015). Without the arts and the contemplation of ethics, conservation may veer towards the ugly and the unethical. Let us not forget the often highly colonial, disruptive and even violent history of conservation (Brockington and Igoe, 2006; Sandlos, 2007) - which has led to the critiques of the social impacts of conservation mentioned earlier. The arts and humanities can provide us with the concepts and techniques to innovate and re-imagine a more socially just, culturally appropriate and, indeed, beautiful way of imagining and achieving conservation (Brennan, 2018; Holm et al., 2015; Polfus et al., 2017). What we are refering to here is the full transformative potential of conservation, which is already an act of resistance. Conservation, we propose, is not a practice limited to a particular place and time but rather one that asks us all to rethink our relationship to nature in ways that lead to the production of healthy environments for humans and non-humans alike. We can learn something here from the work of Indigenous scholars reflecting on Indigenous ways of knowing and viewing human-environment relationships as rooted in deep respect for 'all our relations' across multiple generations (Kimmerer, 2013). Art in a more conventional sense also has the ability to transform our relationship to nature, making us reflect in ways that busy lives do not normally allow for. There is overwhelming evidence that our sense of connection to nature profoundly effects our willingness to protect it (Nisbet et al., 2009). Art, the humanities and philosophy can help us to reconnect and be inspired again.

The conservation community is moving towards more integrative and collaborative and approaches to conservation (Cumming et al., 2015; Guerrero et al., 2015; Tengö et al., 2017; Therville et al., 2017). As diverse teams are constituted to deliver real world solutions to pressing conservation problems, we hope that social scientists, artists and humanities scholars are amongst those represented. However, just as we are asking conservation practitioners and scientists to be willing to grapple with different ideas and types of challenges, so too social scientists, artists and humanities scholars will need to reconsider their way of engaging. Social scientists may need to get better at working in teams, at integrating ideas with other disciplines and pracitioner knowledges, and at communicating their research to diverse audiences of practitioners and policy-makers. Conservation social science needs to remain theoretically grounded, methodologically 
rigorous and thoughtfully executed even as it rises to the challenge of being useful. Practitioners of social science will need to be able to communicate the importance of these aspects of their work. Doing so will further dissuade those with little knowledge of the field to assert its instrumental nature and thus attempt what is often poorly designed social science research that does little to advance conservation.

The social sciences, the arts and the humanities, are poised to play a much greater role in conservation. However, without greater investments and mindful engagement, the potential contributions of the social sciences, arts and humanities to conservation will not be realized. Key conservation bodies (e.g., IUCN, CBD) and policy processes (e.g., IPCC, IPBES) could benefit from greater capacity in social science. Why not also have artists or ethicists in residence? Similarly, conservation NGOs and government agencies responsible for environmental management would benefit from hiring social scientists as they pursue their mandates. Conservation journals (such as this one) also need to be open to, and even actively encourage, publications that address a broader and more innovative set of social science, arts and humanities papers than is typically within their purview. Moving the conservation social sciences, arts and humanities beyond the margin in conservation science will increase their potential to transform conservation paradigms, programs, policies and practices and humanity's relationship to nature, which is arguably the intent of the conservation movement.

Acknowledgements: NJB would like to acknowledge postdoctoral fellowship support from the OceanCanada Partnership at the University of British Columbia and a recent early career award from the Society of Conservation Biology for contributions made to advancing the role of the social sciences in conservation science and policy.

\section{References:}

Bennett, N.J., Roth, R., Klain, S.C., Chan, K.M.A., Christie, P., Clark, D.A., Cullman, G., Curran, D., Durbin, T.J., Epstein, G., Greenberg, A., Nelson, M.P., Sandlos, J., Stedman, R.C., Teel, T.L., Thomas, R.E.W., Veríssimo, D., Wyborn, C., 2017a. Conservation social science: Understanding and integrating human dimensions to improve conservation. Biol. Conserv. 205, 93-108.

Bennett, N.J., Roth, R., Klain, S.C., Chan, K.M.A., Clark, D.A., Cullman, G., Epstein, G., Nelson, M.P., Stedman, R., Teel, T.L., Thomas, R.E.W., Wyborn, C., Curran, D., Greenberg, A., Sandlos, J., Veríssimo, D., 2017b. Mainstreaming the social sciences in conservation. Conserv. Biol. 31, 56-66. https://doi.org/10.1111/cobi.12788

Brennan, R., 2018. Re-storying marine conservation: Integrating art and science to explore and articulate ideas, visions and expressions of marine space. Ocean Coast. Manag. https://doi.org/DOI: 10.1016/j.ocecoaman.2018.01.036 
Brockington, D., Igoe, J., 2006. Eviction for Conservation: A Global Overview. Conserv. Soc. $4,424$.

Büscher, B., Fletcher, R., Brockington, D., Sandbrook, C., Adams, W.M., Campbell, L., Corson, C., Dressler, W., Duffy, R., Gray, N., Holmes, G., Kelly, A., Lunstrum, E., Ramutsindela, M., Shanker, K., 2017. Half-Earth or Whole Earth? Radical ideas for conservation, and their implications. Oryx 51, 407-410. https://doi.org/10.1017/S0030605316001228

Chan, K.M.A., Balvanera, P., Benessaiah, K., Chapman, M., Díaz, S., GómezBaggethun, E., Gould, R., Hannahs, N., Jax, K., Klain, S., Luck, G.W., MartínLópez, B., Muraca, B., Norton, B., Ott, K., Pascual, U., Satterfield, T., Tadaki, M., Taggart, J., Turner, N., 2016. Opinion: Why protect nature? Rethinking values and the environment. Proc. Natl. Acad. Sci. 113, 1462-1465.

https://doi.org/10.1073/pnas.1525002113

Charnley, S., Carothers, C., Satterfield, T., Levine, A., Poe, M.R., Norman, K., Donatuto, J., Breslow, S.J., Mascia, M.B., Levin, P.S., Basurto, X., Hicks, C.C., García-Quijano, C., St. Martin, K., 2017. Evaluating the best available social science for natural resource management decision-making. Environ. Sci. Policy 73, 80-88. https://doi.org/10.1016/j.envsci.2017.04.002

Cumming, G.S., Allen, C.R., Ban, N.C., Biggs, D., Biggs, H.C., Cumming, D.H., De Vos, A., Epstein, G., Etienne, M., Maciejewski, K., others, 2015. Understanding protected area resilience: a multi-scale, social-ecological approach. Ecol. Appl. 25, 299-319.

Doak, D.F., Bakker, V.J., Goldstein, B.E., Hale, B., 2014. What is the future of conservation? Trends Ecol. Evol. 29, 77-81. https://doi.org/10.1016/j.tree.2013.10.013

Gray, N.J., Gruby, R.L., Campbell, L.M., 2014. Boundary Objects and Global Consensus: Scalar Narratives of Marine Conservation in the Convention on Biological Diversity. Glob. Environ. Polit. 14, 64-83. https://doi.org/10.1162/GLEP_a_00239

Gruby, R.L., Gray, N.J., Campbell, L.M., Acton, L., 2016. Toward a Social Science Research Agenda for Large Marine Protected Areas: Social science and large MPAs. Conserv. Lett. 9, 153-163. https://doi.org/10.1111/conl.12194

Guerrero, A.M., Mcallister, R.R.J., Wilson, K.A., 2015. Achieving Cross-Scale Collaboration for Large Scale Conservation Initiatives. Conserv. Lett. 8, 107-117. https://doi.org/10.1111/conl.12112

Harris, P., 2014. Fortress, safe haven or home? The Chagos MPA in political context. Mar. Policy 46, 19-21. https://doi.org/10.1016/j.marpol.2014.01.002

Head, L., 2017. The social dimensions of invasive plants. Nat. Plants 3, 17075. https://doi.org/10.1038/nplants.2017.75

Holmes, G., Cavanagh, C.J., 2016. A review of the social impacts of neoliberal conservation: Formations, inequalities, contestations. Geoforum 75, 199-209. https://doi.org/10.1016/j.geoforum.2016.07.014

Holm, P., Adamson, J., Huang, H., Kirdan, L., Kitch, S., McCalman, I., Ogude, J., Ronan, M., Scott, D., Thompson, K.O., Travis, C., Wehner, K., 2015. Humanities for the Environment-A Manifesto for Research and Action. Humanities 4, 977992. https://doi.org/10.3390/h4040977 
Kimmerer, R., 2013. Braiding Sweetgrass: Indigenous Wisdom, Scientific Knowledge and the Teachings of Plants. Milkweed Editions, Minneapolis, MN.

Moon, K., Blackman, D., 2014. A guide to understanding social science research for natural scientists. Conserv. Biol. 28, 1167-1177.

https://doi.org/10.1111/cobi.12326

Nisbet, E.K., Zelenski, J.M., Murphy, S.A., 2009. The Nature Relatedness Scale: Linking Individuals' Connection With Nature to Environmental Concern and Behavior. Environ. Behav. 41, 715-740. https://doi.org/10.1177/0013916508318748

Polfus, J., Simmons, D., Neyelle, M., Bayha, W., Andrew, F., Andrew, L., Merkle, B., Rice, K., Manseau, M., 2017. Creative convergence: exploring biocultural diversity through art. Ecol. Soc. 22. https://doi.org/10.5751/ES-08711-220204

Sandlos, J., 2007. Hunters at the Margin: Native People and Wildlife Conservation in the Northwest Territories. UBC Press, Vancouver, Canada.

Tengö, M., Hill, R., Malmer, P., Raymond, C.M., Spierenburg, M., Danielsen, F., Elmqvist, T., Folke, C., 2017. Weaving knowledge systems in IPBES, CBD and beyond-lessons learned for sustainability. Curr. Opin. Environ. Sustain. 26-27, 17-25. https://doi.org/10.1016/j.cosust.2016.12.005

Therville, C., Mathevet, R., Bioret, F., Antona, M., 2017. Navigating protected areas as social-ecological systems: integration pathways of French nature reserves. Reg. Environ. Change 1-12. https://doi.org/10.1007/s10113-017-1231-4

West, P., Brockington, D., 2006. An anthropological perspective on some unexpected consequences of protected areas. Conserv. Biol. 20, 609-616. https://doi.org/10.1111/j.1523-1739.2006.00432.x

West, P., Igoe, J., Brockington, D., 2006. Parks and peoples: The social impact of protected areas. Annu. Rev. Anthropol. 35, 251-277. https://doi.org/10.1146/annurev.anthro.35.081705.123308

Wilson, E.O., 2016. Half-Earth: Our Planet's Fight for Life. W. W. Norton \& Company, New York, USA. 